Journal of Teacher Education for Sustainability, vol. 16, no. 2, pp. 18-38, 2014

\title{
Analysis of Mythical-Metaphorical Narratives as a Resource for Education in the Principles and Values of Sustainability
}

\author{
Grian-Antonio Cutanda \\ University of Granada, Spain \\ María Ángeles Murga-Menoyo \\ UNESCO Chair of Environmental Education and Sustainable Development \\ National University of Distance Education, Spain
}

\begin{abstract}
This research aims to prove that the mythical-metaphorical narratives from cultures in harmonic relationship with their natural environment can be considered as an educational resource within the context of education for sustainable development. Using the Earth Charter as a basis and after establishing as analysis categories the competencies that education should foster in the students from this perspective, a content analysis of 28 stories was performed. The results endorse the existing coherence between the materials analysed and the principles and values that the Earth Charter's text reflects and the relevance of these materials as educational resources within the framework of education for sustainable development.
\end{abstract}

Key words: educational resource, mythical-metaphorical narratives, education for sustainable development, complex thinking

\section{The Earth Charter, Mythical Narratives and ESD}

Faced with the challenge of sustainable development, education has to deal with a complex problem that calls for a paradigmatic change of course to consolidate principles and values consistent with this approach. The values that have been neglected or even forgotten, by the most powerful countries, contribute to the widespread crisis we are suffering today.

In December 2002, the United Nations (UN) declared the Decade of Education for Sustainable Development (DESD) (2005-2014), making an international call to re-orient education and training towards this new sociocultural model. With this, the transformative function of education was recognised once again, claiming its role as a force for change that, extended to all areas of global society, could foster a culture of sustainability. Immediately, the United Nations Educational Scientific and Cultural Organisation (UNESCO, 2003), agency responsible for promoting this initiative, resolved to "recognize 
the Earth Charter as an important ethical framework for sustainable development and acknowledge its ethical principles, its objectives and its contents" while affirming the Member States' to utilise this text as an educational tool (p. 35).

The answer to the challenge offered by the DESD requires an intense work of renewal. Among other things, there will be a need for new methodologies and educational resources, which will have to show a sound coherence with those new educational goals. In times of change, which are always times for opportunities, finding new methodological ways, tools or resources is an obligatory task; a task to which we intend to join with the research presented in this paper.

The epistemological principles and values of sustainability are present, in many cases, in the mythical stories of cultures and traditions that were able to keep their connection with nature and the Earth. These are peoples who never forgot the importance of relationships, interconnections and interdependence between the multiple elements of reality. These are peoples who "have not done our terrible split [between reason and heart]" (Arocha, 1994, p. 1). This is one of the reasons why, as Gadotti (2000) pointed out, "ecology often revalues in its practices the traditions of the oldest cultures" (p. 167); traditions that have been not only capable of transmitting the values of sustainability, but also of conveying the holistic and systemic worldview that characterises this approach.

Taking all of this into account, this study adopts an initial premise; namely, that myths, legends, tales, fables and parables, through which these cultures shaped their worldview and the world of their children and young people, have a powerful potential to address the educational challenge posed by sustainable development. This is a premise that, on the other hand, was subscribed by UNESCO (2012). And, using content analysis as a research methodology, it seeks to confirm this thesis. We intend to justify the potential relevance of mythical narrative materials from different cultures as an educational resource. And we intend to do this highlighting that their contents and symbols represent a guide consistent with the typical principles, values and attitudes of that citizenship that is emerging today, attuned with a planetary consciousness, which, albeit slowly, is progressing day by day.

This research aims to identify mythical, metaphorical narratives from different cultures which can illustrate the epistemological principles and values of sustainable development as stated in the Earth Charter. Both the UN and UNESCO endorse this document as a recognised benchmark of an educational model for sustainable development. A large number of governments have signed their support for the Earth Charter.

\section{Background}

Scientific literature on experiences and practical applications of metaphorical mythical narratives as educational resources is related, in most cases, to the promotion of fantasy, imagination, emotional intelligence, multiculturalism or body language (Cid, 2009; Egan, 1986, 2012; González León, 2010; López Valero \& Encabo, 2001; López Valero, Encabo, Moreno, \& Jerez, 2003; Páez, 2011; Swaim, 1997; Zabel, 1991). Mainly, it offers models of curriculum organisation and implementation guidelines in classrooms, not only in the area of language and literature, but also in the teaching of mathematics (Cidoncha, 2011; Marín, 1999, 2003, 2007; Saá Rojo, 2002; Schiller \& Peterson, 1997) or new technologies (Batelaan \& Passantino, 2000; Jansen \& Culpeper, 1996). 
In the field of environmental education - an international movement that has been pioneering the teaching of the values and principles of sustainable development - we can highlight an internationally recognised programme that, in the eighties of the last century, based on Native American myths, used participatory educational strategies: storytelling, free association, drama, dance and sharing objects (Caduto, 1984; Caduto \& Bruchac, 1988, 1991, 1994a, 1994b). Subsequent publications, although not abundant, collected other experiences that reinforce this line of work (Brody, Goldspinner, Green, \& Leventhal, 2002; Ellis, 2012; Livo, 2000, 2003; MacDonald, 1999). However, we have no evidence of research linking mythical-metaphorical narratives with the Earth Charter or highlighting the potential of this kind of stories as a resource for education for sustainable development. A model described in the educational strategy for sustainable development of the United Nations Economic Commission for Europe, "as being underpinned by an ethic of solidarity, equality and mutual respect among people, countries, cultures and generations; it is development in harmony with nature, meeting the needs of the present generation without compromising the ability of future generations to meet their own needs" (UN, 2011, p. 1). We have only found, in approximate terms, the study of Ovsienko (2007), which suggests the use of proverbs, sayings, stories and songs - Tartars and Russians - as a way to present significant concepts of this model in a flexible and interactive way, and the work of Cary (2007), who uses quotations from the famous book "The Little Prince" by Antoine de Saint-Exupéry, to convey the principles of the Earth Charter to children. This research aims to fill this gap.

\section{Objective}

The objective of this work is to provide a basic list of mythical and metaphorical stories from native peoples that reflect the principles and values of the sustainability paradigm in their texts; stories that, according to their characteristics and educational potential, could be used as a resource for teaching and learning in the context of education for sustainable development.

\section{Methodology}

This research has been carried out in two phases. In the first phase, we compiled a list of mythical stories in line with the four axes that articulate the text of the Earth Charter: Respect and care for the community of life; Ecological integrity; Social and economic justice; Democracy, nonviolence and peace (the Earth Charter Initiative [ECI], 2000). In the second phase, we conducted the study that has met the most specific objective of this work.

\section{Selection of Narratives}

To identify the list of stories, we resorted to the existing literature on myths, legends, stories and other mythical and metaphorical materials, characterised by a harmonious view of the relationship between humans and their natural environment, and away from those strictly anthropocentric approaches to the universe that have lead us to the current environmental destruction (Brown, 1982; Gadotti, 2000; Taylor, 2000). 
The methodical and systematic search in the digital databases, including very old books recently digitised and files of cultural materials from oral tradition located on websites, with more than 1,400 stories from Native American cultures - allowed us to identify a total of 28 mythical and metaphorical texts from 19 cultures and traditions of four continents (Table 1 ).

Table 1

Cultural and Geographic Distribution of the Sample

\begin{tabular}{lccl}
\hline Continents & $\begin{array}{c}\text { Number of } \\
\text { stories }\end{array}$ & $\begin{array}{c}\text { Number of cultures } \\
\text { and traditions }\end{array}$ & \multicolumn{1}{c}{ Cultures/Traditions } \\
\hline Africa & 2 & 1 & Yoruba \\
\hline America & 18 & 13 & $\begin{array}{l}\text { Onondaga, Cheroqui, Muskogee (Creek), } \\
\text { Lakota, Okanagan, Pemón, Abenaki, } \\
\text { MicMac, Iroquesa, Wampanoag, Nisqually, } \\
\text { Cree, Hopi }\end{array}$ \\
\hline Asia & 5 & 3 & Tibetan Buddhism, Buddhism Indian, Judaism \\
\hline America-Asia & 1 & 1 & Inuit (Eskimo) \\
\hline Oceania & 2 & 1 & Australian aboriginal \\
\hline Total & 28 & 19 & \\
\hline
\end{tabular}

In this selection, we took into account seven criteria consistent with the principles and values of education for sustainable development (ECI, 2000; UN, 2011; UNESCO, 1997, 2005, 2010, 2012). These are the criteria: a) cultural diversity; b) planetarity; c) natural harmony (interdependence between species and austerity in the use of natural resources); d) social harmony (social justice, collaboration and cooperation, consensual resolution of conflicts, community involvement); e) traditionality (transmitted down through generations, preferably in oral form); f) inspiring and full of ideals (to reach the motivational core of the people); g) beauty, affection and sensitivity. On the other hand, we have observed the rules of exhaustiveness, representativeness, homogeneity and relevance.

The 28 selected stories constituted the non-probabilistic but intentional sample that we subjected to content analysis. In this sample, the number of stories belonging to Native American cultures and traditions is far superior to other cultures and geographic regions, and there is a total absence of stories from European cultures and traditions. Certainly, this is a limitation of this research.

\section{Analysis Categories}

Since we were dealing here with a verification analysis, the categories for the content analysis were the most significant descriptors of the competencies to achieve through education for sustainable development. They were established following a review of the educational literature published in three main lines of research. The first one centred on the model of education for sustainable development (Aznar \& Ull, 2013; Aznar, MartinezAgut, Palacios, Piñero, \& Ull, 2011; Barrón, Navarrete, \& Ferrer-Balas, 2010; Beringer, 2007; Geli, 2005; Murga-Menoyo, 2013; Novo, 2006; UNESCO, 1997, 2004, 2005 , 2006, 2010, 2012). The second one focused on complex-systems thinking, a central pillar of sustainability (Boardman \& Sauser, 2008; Delgado, 2008; Gadotti, 2000; 
Hedlund-de Witt, 2013; Hedlund-de Witt, de Boer, \& Boersema, 2014; Inelmen, 2010; Jacobson \& Wilensky, 2006; Morin, 1992; 1996; 2001; Palacio \& Ochoa, 2011), and the third one dealt with the Earth Charter (Antunes \& Gadotti, 2005; Fernández Herrería \& Carmona, 2010; Murga-Menoyo, 2009; Vázquez, 2010).

The total of 23 categories were constructed. Of these, twelve categories outline the epistemological principles, and eleven categories outline the values and attitudes of sustainability, which were expressed with a minimum of words or word fragments as possible (Delgado \& Del Villar, 1995) and were operationally and accurately defined to be subject to expert judgment. The respective operational definitions are presented in Tables 2 and 3.

Table 2

Categories Related to Epistemological Principles

\begin{tabular}{ll}
\hline \multicolumn{1}{c}{ Categories } & \multicolumn{1}{c}{ Operational Definition } \\
\hline $\begin{array}{l}\text { Inclusive systems thinking } \\
\text { (IST) }\end{array}$ & $\begin{array}{l}\text { It finds evidence of cognitive operations of synthesis, establish- } \\
\text { ment of relationships and interconnections. Parts are considered } \\
\text { as components of an interrelated and interdependent whole }\end{array}$ \\
\hline $\begin{array}{l}\text { Cognitive, affective ethical } \\
\text { and aesthetic integration } \\
\text { (Int) }\end{array}$ & $\begin{array}{l}\text { Elements from at least three types of components are articulated, } \\
\text { including the following: cognitive, affective, ethical and } \\
\text { aesthetic }\end{array}$ \\
\hline $\begin{array}{l}\text { Theoretical and practical } \\
\text { coherence (Coh) }\end{array}$ & $\begin{array}{l}\text { There is a close relationship between theory and practice, } \\
\text { between ideas and actions }\end{array}$ \\
\hline $\begin{array}{l}\text { Dialogic cognitive } \\
\text { operations (DOp) }\end{array}$ & $\begin{array}{l}\text { Dialogical relations are observed, including a conciliation } \\
\text { between antagonistic or opposing elements }\end{array}$ \\
\hline Contextualisation (Ctx) & $\begin{array}{l}\text { Relationships are established between the requirements of the } \\
\text { immediate context, actions and their consequences at the local } \\
\text { and global level, or changes in global context evoke actions in } \\
\text { the immediate context }\end{array}$ \\
\hline Cotidianity (Cot) & It gives value to everyday experiences \\
\hline $\begin{array}{l}\text { Recursive cognitive } \\
\text { operations (ROp) }\end{array}$ & $\begin{array}{l}\text { Recursive cognitive operations, reflexiveness, self-criticism and } \\
\text { ethical assessment of own behaviours are inferred. }\end{array}$ \\
\hline $\begin{array}{l}\text { Motivation for self- } \\
\text { improvement (SIm) }\end{array}$ & $\begin{array}{l}\text { There is an individual search of changes and challenges to meet } \\
\text { personal needs }\end{array}$ \\
\hline $\begin{array}{l}\text { Participation, collaboration } \\
\text { and cooperation (PCC) }\end{array}$ & $\begin{array}{l}\text { The characters take part in decision making or collective action; } \\
\text { they collaborate and cooperate to achieve a goal }\end{array}$ \\
\hline $\begin{array}{l}\text { Tolerance of uncertainty } \\
\text { (Tol) }\end{array}$ & $\begin{array}{l}\text { There are adaptive attitudes and responses at an affective level } \\
\text { to different circumstances and changes; mechanisms of tole- } \\
\text { rance of uncertainty }\end{array}$ \\
\hline $\begin{array}{l}\text { Creative responses to } \\
\text { uncertainty (CrR) }\end{array}$ & $\begin{array}{l}\text { Uncertainty and change become a reason for seeking creative } \\
\text { operational responses and alternative scenarios }\end{array}$ \\
\hline $\begin{array}{l}\text { Metaphorical-analogical } \\
\text { thinking (MAT) }\end{array}$ & $\begin{array}{l}\text { It uses metaphor or analogy to illustrate concepts, ideas or } \\
\text { attitudes }\end{array}$ \\
\hline &
\end{tabular}


Table 3

Categories Related to Values and Attitudes

\begin{tabular}{|c|c|}
\hline Categories & Operational Definition \\
\hline $\begin{array}{l}\text { Precedence of common } \\
\text { interest (CIn) }\end{array}$ & $\begin{array}{l}\text { It conveys the idea that social or ecological common interest } \\
\text { takes precedence over personal interest }\end{array}$ \\
\hline $\begin{array}{l}\text { Appreciation of the inter- } \\
\text { dependence relationships } \\
\text { (Itd) }\end{array}$ & $\begin{array}{l}\text { The interdependence between humans or between humans and } \\
\text { the environment are explicitly asserted or inferred }\end{array}$ \\
\hline $\begin{array}{l}\text { Expanded sense of identity } \\
\text { (EId) }\end{array}$ & $\begin{array}{l}\text { The sense of individual or group identity is blurred and/or } \\
\text { expands in the direction of the global }\end{array}$ \\
\hline $\begin{array}{l}\text { Sense of belonging to the } \\
\text { community of life (CmL) }\end{array}$ & $\begin{array}{l}\text { They display feelings or sense of respect, affection, considera- } \\
\text { tion or care for other humans or non-human or even for not- } \\
\text { living elements of nature }\end{array}$ \\
\hline sponsibility & $\begin{array}{l}\text { It establishes values of equity and social justice, fair valuation } \\
\text { of things, awareness of the relationship between local and global } \\
\text { realities, about consequences of our actions on the present com- } \\
\text { munity of life }\end{array}$ \\
\hline $\begin{array}{l}\text { Diachronic co-responsibility } \\
\text { (DCr) }\end{array}$ & $\begin{array}{l}\text { It establishes values of equity and social justice, fair valuation } \\
\text { of things, awareness of the relationship between local and global } \\
\text { realities, about consequences of our actions on the future com- } \\
\text { munity of life }\end{array}$ \\
\hline $\begin{array}{l}\text { Solidarity and austerity } \\
\text { (SaA) }\end{array}$ & $\begin{array}{l}\text { It calls for solidarity and support to the needy, as well as for } \\
\text { moderation, austerity and simplicity in lifestyle }\end{array}$ \\
\hline $\begin{array}{l}\text { Empathy and affectivity } \\
\text { (EaA) }\end{array}$ & $\begin{array}{l}\text { They reflect concerns or feelings of empathy and affection for } \\
\text { other humans or non-humans or even for non-living nature }\end{array}$ \\
\hline $\begin{array}{l}\text { Respect for life and non- } \\
\text { violence (LNv) }\end{array}$ & $\begin{array}{l}\text { They adopt an attitude of respect for life and non-violence in } \\
\text { conflicts. The characters try to avoid damage to any other } \\
\text { living or non-living element of nature }\end{array}$ \\
\hline $\begin{array}{l}\text { Critical and active social } \\
\text { attitude (CAA) }\end{array}$ & $\begin{array}{l}\text { They show critical and active social attitudes to social and } \\
\text { environmental problems, behaviours of participation, coopera- } \\
\text { tion and collaboration within a group }\end{array}$ \\
\hline $\begin{array}{l}\text { Respe } \\
\text { dialog }\end{array}$ & $\begin{array}{l}\text { They show relation attitudes based on respect, dialogue and } \\
\text { active listening as a way of dealing with conflict }\end{array}$ \\
\hline
\end{tabular}

\section{Analysis Method and Validation}

The unit of information on which the analysis has been realised is the paragraph, as it is common in attitudes and values studies. And the mode of computation for the units of analysis was the presence-absence of items in each category. We repeated the analysis of each text after a sufficient time interval to avoid potential error due to mental pollution and refine the assignment of categories to the analysis units.

As for the types of analysis, we used the following: verification analysis to confirm the presence of the pre-established categories in the mythical stories; qualitative analysis to prioritise the consistence of the stories contents with the categories, and not so much to their frequency.

The analysis of each text unit has been subjected to replication; that is, the analysis process has been duplicated, leaving a gap of five days between both performances in order to prevent contamination. In the second run, the entries of the first analysis were 
reviewed one by one in order to refine, in a more strict and rigorous way, the assignment of each unit to its corresponding category.

On the other hand, the principles and values inspiring the text of these stories are closely interrelated. Therefore, we have not considered appropriate to apply the principle of mutual exclusion to the categories of analysis. In fact, in many cases, the units of analysis were assigned to several categories.

\section{Results and Discussion}

\section{List of Mythical Stories Consistent with the Core Principles of the Earth Charter}

In the stories selected, 28 altogether, there is a range of mythical narratives whose contents can illustrate the epistemological principles and values of sustainable development as reflected in the different sections of the text of the Earth Charter. The list of stories is provided in Table 4.

Table 4

Mythical Stories Consistent with the Earth Charter

\begin{tabular}{|c|c|}
\hline $\begin{array}{l}\text { Principles of } \\
\text { the Earth Charter }\end{array}$ & Mythical Texts ${ }^{(*)}$ \\
\hline 1 & 2 \\
\hline Preamble & $\begin{array}{l}\text { (1) The Secret of Dreaming (Australian Aboriginal) (Poulter, 1988) } \\
\text { (2) The Earth on Turtle's Back (Onondaga) (Caduto \& Bruchac, } \\
\text { 1988, pp. 25-26) } \\
\text { (3) The Four Races (Cherokee) (McFadden, 1989, pp. 102-103) } \\
\text { (4) How Grandmother Spider Stole the Sun (Muskogee/Creek) } \\
\text { (Caduto \& Bruchac, 1988, pp. 49-50) } \\
\text { (5) The Pact of Fire (Lakota Sioux) (Loki's Gift, 2009) }\end{array}$ \\
\hline $\begin{array}{l}\text { Respect and care for } \\
\text { the community of life }\end{array}$ & $\begin{array}{l}\text { (6) The White Buffalo Calf Woman (Lakota Sioux) (Caduto \& } \\
\text { Bruchac, 1988, p. 187-188; Brown, 1989, pp. 3-9) } \\
\text { (7) Earth Woman (Okanagan) (Leeming, 2010, p. 214) } \\
\text { (8) Buddha and the Swan (Buddhism) (Fisher, 1996, pp. 45-47) } \\
\text { (9) How the Kangaroo Got Her Pouch (Australian aboriginal) (Flood, } \\
\text { Strong \& Flood, 1999, pp. 248-251) } \\
\text { (10) The Legend of Shambhala (Tibetan Buddhism) (Dmitrieva, 1997) } \\
\text { (11) The Old Man and the Fig Tree (Judaism) (Bleefeld \& Shook, } \\
\text { 2001, pp. 61-62) }\end{array}$ \\
\hline Ecological integrity & $\begin{array}{l}\text { (12) Awi Usdi, the Little Deer (Cherokee) (Caduto \& Bruchac, 1988, } \\
\text { pp. 173-174) } \\
\text { (13) Wadaká Piapó: The Tree of Life (Pemon) (De Cora, 2005) } \\
\text { (14) Gluscabi and the Game Animals (Abenaki) (Caduto \& Bruchac, } \\
\text { 1988, pp. 165-167) } \\
\text { (15) Gluscabi and the Wind Eagle (Abenaki) (Caduto \& Bruchac, } \\
\text { 1988, pp. 67-71) }\end{array}$ \\
\hline $\begin{array}{l}\text { Social and economic } \\
\text { justice }\end{array}$ & $\begin{array}{l}\text { (16) How Fox Saved the People (Inuit/Eskimo) (First People (2012c) } \\
\text { (17) Koluscap and the Water Monster (Micmac) (Caduto \& Bruchac, } \\
\text { 1988, pp. 81-84) } \\
\text { (18) The Legend of the First Woman (Cherokee) (First People, 2012d) } \\
\text { (19) Firstman and Firstwoman (Cherokee) (Indian Stories, n.d.) }\end{array}$ \\
\hline
\end{tabular}


Sequel to Table 4.

\begin{tabular}{ll}
\hline \multicolumn{1}{c}{ (20) The Staff of Oranyan (Yoruba) (Ogumefu, 2007, pp. 40-41) } \\
& (21) The Banyan Deer (Indian Buddhism) (Martin, 1990, pp. 97-102) \\
\hline $\begin{array}{l}\text { Democracy, non- } \\
\text { violence, and peace }\end{array}$ & (22) The Peacemaker and the Tree of Peace (Iroquois) (First People, \\
& 2012a) \\
& (23) The Circle of Life and the Clambake (Wampanoag) (Bruchac \& \\
Caduto, 1995, pp. 21-24) \\
(24) The Ants and the Treasure (Yoruba) (Ogumefu, 2007, pp. 19-21) \\
(25) Loo-Wit, the Fire-Keeper (Nisqually) (Caduto \& Bruchac, 1988, \\
pp. 41-43) \\
(26) Hiawatha the Unifier (Iroquois) (First People, 2012b) \\
\hline Epilogue & (27) The Legend of the Rainbow Warriors (Lakota Sioux, Hopi, Cree, \\
Cherokee) (Fuller-Anderson, 2011) \\
(28) The Shambhala Warrior (Tibetan Buddhism) (Macy, 2002; \\
Choegyal Rinpoche, 2012)
\end{tabular}

(*) The number in parentheses corresponding to each story is the reference toTable 6 and Table 7

Some of these narratives are related with the contents of the Earth Charter mostly in an implicit way, as those which we have linked with the preamble and the epilogue of the text. Other are better suited for certain specific principles, given the emphasis they devote to describing exemplary behaviours and situations of each case.

\section{Epistemological Principles, Values and Attitudes of Sustainability in Mythical Stories}

The in-depth content analysis was carried out on the 28 mythical stories selected. We found a total of 507 significant excerpts suited to detach and assign to the established categories. Among them, 288 excerpts have been assigned to categories of complexsystems thinking and 219 to categories related to values. On the other hand, it should be noted that each story could have one or more excerpts related to a specific category. That is why we finally chose to simply count the presence or absence of excerpts suited to be linked to each category.

The data highlight the tuning of the mythical, metaphorical materials analysed with the epistemological principles, values and attitudes of the Earth Charter. Given that, at least, more than $60 \%$ of the analysis categories are reflected in the excerpts of the stories analysed.

As can be seen in Table 5, there is a greater saturation of data in the categories that reflect characteristics of the systemic thinking $(72.02 \%)$ than in those which relate to attitudes and values $(63.9 \%)$. To understand this disharmony, it must be borne in mind that these stories were selected on the content of the principles of the Earth Charter, regardless of whether they reflected more or fewer categories of sustainability values, but only those categories related to the principle in question. As an example, the story "Awi Usdi, the Little Deer" explains one of the principles of the Earth Charter to perfection, as well as those values inherent to it. But this story leaves aside other values and attitudes of sustainability which, however, are conveyed through other stories. 
Table. 5

Presence/Absence of Excerpts of Different Categories in the Whole of the Mythical Stories

\begin{tabular}{lccc}
\hline & Presence & Absence & Presence $(\%)$ \\
\hline Complex-systems thinking categories & 242 & 94 & 72.02 \\
\hline Values of sustainability categories & 197 & 111 & 63.96 \\
\hline
\end{tabular}

Presence - Presence of categorisable excerpts by a mythical story Absence - Absence of categorisable excerpts by a mythical story

Presence $(\%)$ - Percentage of presence for categorisable excerpts within the total possible

The data provide a preliminary overview of the situation. We have found that a high percentage of the analysed stories contained in their texts elements - often loaded with a powerful symbolic force - able to encourage listeners and readers (students) both a complex, relational thinking and the values and attitudes necessary to strengthen communities characterised by sustainable development. And this evidence supports the relevance of these stories as potentially useful resources in the context of learning processes.

The conception of mythical-metaphorical stories as scenarios representing human and social problems allows us to recover their original pedagogical purpose, which is the mainstay of these pieces of oral tradition. In the present case, in our first approach to the content of the texts, we can see that the plot itself reflects a worldview that holds high levels of consistency with the principles and values of sustainable development. We shall use a brief synopsis of three of these stories to, by way of examples, support this assertion.

In "Gluscabi and the Game Animals", the main character, fed up with the everyday stress and uncertainty resulting from hunting, asks Grandmother Woodchuck to make him a big bag, in which he gets to shut up all the animals. Delighted with his feat, because he thinks he will never have to struggle to find food, Gluscabi tells Grandmother Woodchuck what he has done. But she puts Gluscabi right, explaining to him that animals get sick and die in captivity; and ultimately there will be no food for anyone, neither for him nor for generations to come. Moreover, she makes him see the advantages to face the difficulties of hunting, which physically and mentally strengthen both the hunter and the animal. Gluscabi realises his mistake and releases the animals.

In the second story, "Gluscabi and the Wind Eagle", he goes out with his canoe to hunt ducks, but the wind hampers his task. Gluscabi takes a long trip up to the mountain where there is a great eagle that produces the wind with his wings. Gluscabi tricks the eagle, binds him and slides him down into a large crevice. When he returns and goes out with his canoe once again, Gluscabi realises that the air is very hot, the water grows dirty and smells bad; there is so much foam on the water he can hardly paddle. When he asks Grandmother Woodchuck, she explains the benefits of wind to the community of life. Gluscabi rectifies and the balance is restored.

In the third story, "The Banyan Deer", this character volunteers to be sacrificed in place of a pregnant doe. And when the king sees his greatness, he spares his life and grants him a wish. Then, the banyan deer thinks not only in his immediate, local context (his herd and the neighboring herd), but also in the more distant, global context, finally asking the king to respect the lives of all animals, starting with four-footed animals and then asking for birds and fish. 
The poetic plot of these stories reflects the interrelationships and mutual interdependencies among the human and non-human living beings and the forces of nature. They also aim to teach the need to respect the biocapacity limits of the territory, not only for the sake of the present, but also future generations. And they present behaviours supported in values such as compassion, generosity or consistency. After various ups and downs, in which the protagonist's courage is tested and he rectifies his mistakes, the stories ends by strengthening harmony in the community of life.

This systemic and compassionate view of reality is the common denominator of the plots in these stories. We also find in them paragraphs or sentences in which this approach is made explicit, as we show below.

For the purposes of an orderly presentation of our qualitative analysis, the discussion will be structured into two subsections: one dealing with epistemological principles and the other dealing with values.

For the sake of clarity, interpretations shall be accompanied by examples of paragraphs assigned exclusively to a single category. However, it should be noted that, in practice, the vast majority of the units of analysis reflect both principles and values, in which case they have been assigned to both categories.

Epistemological principles. The data for categories related to the principles of complex thinking present in the mythical stories analysed are shown in Table 6. It should be noted here that 10 of the 12 categories are reflected, at least, in more than $64 \%$ of the tales, reaching over $71 \%$ in nine of the categories. Only two of them, "Dialogic Cognitive Operations" and "Motivation for Self-Improvement", had lower results, appearing the first of these categories in 12 stories and the second one in 11, out of the total of 28 stories.

Table 6

Categories Related to Epistemological Principles Present in the Stories Categories Related to Epistemological Principles

\begin{tabular}{|c|c|c|c|c|c|c|c|c|c|c|c|c|c|c|}
\hline & (*) & $\begin{array}{l}\text { IST } \\
\end{array}$ & Int & Coh & DOp & Ctx & Cot & ROp & SIm & PCC & Tol & $\mathrm{CrR}$ & MAT & Total \\
\hline 1 & 2 & 3 & 4 & 5 & 6 & 7 & 8 & 9 & 10 & 11 & 12 & 13 & 14 & 15 \\
\hline \multirow{15}{*}{ 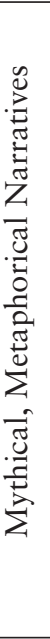 } & 1 & • & $\cdot$ & • & - & & - & - & & • & • & • & - & 10 \\
\hline & 2 & & $\cdot$ & - & - & - & - & - & - & - & & - & - & 10 \\
\hline & 3 & • & & & - & & - & & - & • & & & - & 6 \\
\hline & 4 & $\cdot$ & $\cdot$ & $\cdot$ & & $\cdot$ & $\cdot$ & . & $\cdot$ & $\cdot$ & $\cdot$ & $\cdot$ & $\cdot$ & 10 \\
\hline & 5 & $\cdot$ & $\cdot$ & $\cdot$ & & & $\cdot$ & $\cdot$ & & $\cdot$ & $\cdot$ & $\cdot$ & $\cdot$ & 9 \\
\hline & 6 & $\cdot$ & $\cdot$ & - & & & - & & & • & • & & - & 7 \\
\hline & 7 & $\cdot$ & $\cdot$ & $\cdot$ & & & - & - & & & & & - & 6 \\
\hline & 8 & $\cdot$ & $\cdot$ & $\cdot$ & & $\cdot$ & • & - & & & • & • & • & 9 \\
\hline & 9 & $\cdot$ & $\cdot$ & . & & $\cdot$ & • & • & & 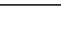 & 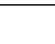 & - & - & 7 \\
\hline & 10 & $\cdot$ & . & $\cdot$ & & $\cdot$ & & 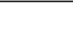 & & $\cdot$ & $\cdot$ & . & $\cdot$ & 6 \\
\hline & 11 & & & $\cdot$ & & - & • & • & & & & & • & 5 \\
\hline & 12 & $\cdot$ & $\cdot$ & • & . & $\cdot$ & - & $\cdot$ & $\cdot$ & . & • & - & $\cdot$ & 12 \\
\hline & 13 & & • & $\cdot$ & & $\cdot$ & - & & & • & • & - & - & 8 \\
\hline & 14 & $\cdot$ & $\cdot$ & $\cdot$ & • & $\cdot$ & $\cdot$ & $\cdot$ & • & & • & $\cdot$ & • & 11 \\
\hline & 15 & $\cdot$ & • & & - & $\cdot$ & • & - & • & • & • & - & • & 11 \\
\hline
\end{tabular}


Sequel to Table 6.

\begin{tabular}{|c|c|c|c|c|c|c|c|c|c|c|c|c|c|}
\hline $\begin{array}{ll}1 & 2 \\
\end{array}$ & 3 & 4 & 5 & 6 & 7 & 8 & 9 & 10 & 11 & 12 & 13 & 14 & 15 \\
\hline 16 & $\cdot$ & - & & - & • & & • & & • & & • & • & 8 \\
\hline 17 & • & • & - & & $\cdot$ & - & & & & $\cdot$ & - & $\cdot$ & 8 \\
\hline 18 & & - & - & & • & - & • & • & • & - & - & • & 10 \\
\hline 19 & & - & & - & & - & • & $\cdot$ & & • & • & $\cdot$ & 8 \\
\hline 20 & & • & • & • & . & • & • & & • & . & • & • & 10 \\
\hline 21 & • & • & - & & - & - & - & • & • & • & • & $\cdot$ & 11 \\
\hline 22 & & • & & $\cdot$ & $\cdot$ & $\cdot$ & $\cdot$ & & $\cdot$ & $\cdot$ & • & • & 9 \\
\hline 23 & $\cdot$ & - & - & & • & • & $\cdot$ & - & $\cdot$ & $\cdot$ & $\cdot$ & - & 11 \\
\hline 24 & & - & - & & - & - & - & & • & & • & . & 8 \\
\hline 25 & & - & & & & $\cdot$ & $\cdot$ & & & $\cdot$ & • & $\cdot$ & 6 \\
\hline 26 & & & & - & - & - & & • & $\cdot$ & $\cdot$ & $\cdot$ & - & 8 \\
\hline 27 & • & $\cdot$ & • & & - & • & • & & • & $\cdot$ & • & $\cdot$ & 10 \\
\hline 28 & $\cdot$ & $\cdot$ & $\cdot$ & $\cdot$ & $\cdot$ & & & & $\cdot$ & & • & $\cdot$ & 8 \\
\hline T. & 18 & 24 & 20 & 12 & 21 & 25 & 20 & 11 & 20 & 20 & 23 & 28 & 242 \\
\hline
\end{tabular}

${ }^{(*)}$ The number corresponds to the title of each story as shown in Table 4.

Inclusive systems thinking (IST); Cognitive, affective, ethical and aesthetic integration (Int); Theoretical and practical coherence (Coh); Dialogic cognitive operations (DOp); Contextualisation (Ctx); Cotidianity (Cot); Recursive cognitive operations (ROp); Motivation for self-improvement (SIm); Participation, collaboration and cooperation (PCC); Tolerance of uncertainty (Tol); Creative responses to uncertainty (CrR); Metaphorical-analogical thinking (MAT)

As mentioned previously, the scheme of the texts in these stories is inspired by a relational thinking that calls into play multiple - in number and magnitude - and diverse factors. Fragments have been found that point to cognitive operations of building relationships and interconnections; that is, to a perception of the elements as components of an interrelated and interdependent whole. So it is in the following examples:

We have now completed our power so that we the Five Nations Confederacy shall in the future have one body, one mind, and one heart. If any evil should befall us in the future, we shall stand or fall united as one man. ("The Peacemaker and the Tree of Peace")

Without their friend to help them, the Wampanoag wondered how they would survive. They soon found, however, that when they worked for themselves, everything that they needed was there. One of those ways of survival which makes use of all that is around them - Earth, the plants, the animals and the water - is called by them Appanaug. ("The Circle of Life and the Clambake")

We cannot stop the humans from hunting animals. That is the way it was meant to be. However, the humans are not doing things in the right way. If they do not respect us and hunt us only when there is real need, they may kill us all. ("Awi Usdi, the Little Deer")

Also, some stories describe occasions in which there are seemingly contradictory poles - good/evil, diversity/unity, freedom/common good, short term/long term, local/ 
global - providing a dynamic process of complementarities and oppositions that favors the exercise of complex thinking. We can see this, for example, in the following fragment:

So we need the second as well, which is insight into the dependent co-arising of all things. It lets us see that the battle is not between good people and bad people, for the line between good and evil runs through every human heart. We realize that we are interconnected, as in a web, and that each act with pure motivation affects the entire web, bringing consequences we cannot measure or even see. ("The Shambhala Warrior")

Messages are not only implicit in the central plots of these stories, given that sometimes they are conveyed as small wedges sprinkled in the text. Thus, for instance, the following fragments are promoting an awareness of universal interdependence (which is a central element of the Earth Charter):

... we are all connected, like the strands of Grandmother Spider's web... ("How Grandmother Spider Stole the Sun")

[She said that] they would... become as one with the entire human race. ("The Legend of the Rainbow Warriors")

In them, we can find the same worldview that is present in the Earth Charter (ECI, 2000):

As the world becomes increasingly interdependent and fragile...

... we are one human family and one Earth community with a common destiny

(p. 1).

In short, our interpretation of the texts justifies, as quantitative data show, that more than $70 \%$ of the stories analysed can be placed within an epistemological framework characterised by a systemic conception of reality. They are, therefore, useful tools for promoting a complex, holistic and relational thinking. And this kind of thinking is a central element of the sustainability competencies that education for sustainable development should teach.

Values and attitudes. With respect to the data corresponding to the values that explicitly appear in the stories, as shown in Table 7, eight out of the 11 categories are reflected, at least, in more than $64 \%$ of the stories. Only two categories - Expanded Sense of Identity and Diachronic Co-responsibility - have not been reflected in more than half of the stories. But, as stated above, it must be taken into account here that we selected these narratives according to the individual principles of the Earth Charter, not seeking the highest saturation in the categories of its values. However, as a whole, these stories can cover the wide range of basic values of sustainable development. And, in most cases, many of them are complementing each other. 
Table. 7

Categories Related to Values and Attitudes of Sustainability Present in the Stories Categories Related to Values and Attitudes of Sustainability

\begin{tabular}{|c|c|c|c|c|c|c|c|c|c|c|c|c|c|}
\hline & $(*)$ & CIn & Itd & EId & $\mathrm{CmL}$ & $\mathrm{SCr}$ & DCr & $\mathrm{SaA}$ & $\mathrm{EaA}$ & $\mathrm{LNv}$ & CAA & RDA & Total \\
\hline 1 & 2 & 3 & 4 & 5 & 6 & 7 & 8 & 9 & 10 & 11 & 12 & 13 & 14 \\
\hline \multirow{29}{*}{ 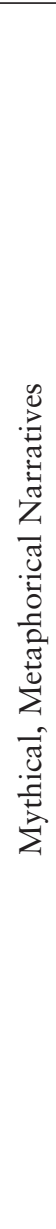 } & 1 & $\cdot$ & $\cdot$ & $\cdot$ & $\cdot$ & $\cdot$ & $\cdot$ & $\cdot$ & $\cdot$ & & $\cdot$ & & 9 \\
\hline & 2 & $\cdot$ & . & & & 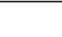 & & • & • & • & . & & 5 \\
\hline & 3 & $\cdot$ & $\cdot$ & 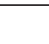 & & • & • & & & • & • & & 6 \\
\hline & 4 & $\cdot$ & $\cdot$ & & $\cdot$ & $\cdot$ & $\cdot$ & & & & $\cdot$ & & 6 \\
\hline & 5 & $\cdot$ & 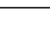 & 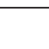 & & • & • & & - & 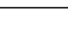 & • & • & 6 \\
\hline & 6 & $\cdot$ & • & $\cdot$ & - & • & & & - & • & & - & 8 \\
\hline & 7 & & $\cdot$ & $\cdot$ & - & 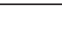 & & & 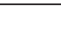 & 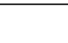 & 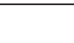 & & 3 \\
\hline & 8 & 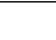 & & & • & $\cdot$ & & • & • & • & - & • & 7 \\
\hline & 9 & $\cdot$ & 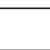 & & • & • & . & • & • & • & & & 6 \\
\hline & 10 & $\cdot$ & 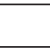 & & $\cdot$ & $\cdot$ & $\cdot$ & . & $\cdot$ & $\cdot$ & • & & 7 \\
\hline & 11 & $\cdot$ & 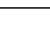 & & 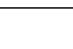 & • & • & & • & & . & & 5 \\
\hline & 12 & 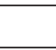 & $\cdot$ & & $\cdot$ & $\cdot$ & $\cdot$ & $\cdot$ & & $\cdot$ & $\cdot$ & & 7 \\
\hline & 13 & $\cdot$ & $\cdot$ & & & $\cdot$ & & $\cdot$ & & & • & • & 6 \\
\hline & 14 & $\cdot$ & $\cdot$ & & $\cdot$ & $\cdot$ & $\cdot$ & $\cdot$ & & & • & • & 8 \\
\hline & 15 & $\cdot$ & $\cdot$ & 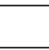 & $\cdot$ & $\cdot$ & $\cdot$ & 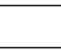 & 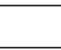 & 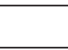 & $\cdot$ & • & 7 \\
\hline & 16 & $\cdot$ & $\cdot$ & $\cdot$ & $\cdot$ & 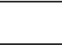 & & $\cdot$ & - & & $\cdot$ & & 7 \\
\hline & 17 & $\cdot$ & $\cdot$ & & & $\cdot$ & & • & • & • & • & • & 8 \\
\hline & 18 & & $\cdot$ & & • & $\cdot$ & & 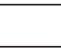 & • & $\cdot$ & $\cdot$ & • & 7 \\
\hline & 19 & 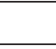 & $\cdot$ & & $\cdot$ & & & • & • & & & • & 5 \\
\hline & 20 & $\cdot$ & 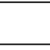 & & & $\cdot$ & 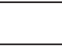 & $\cdot$ & $\cdot$ & 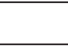 & $\cdot$ & & 5 \\
\hline & 21 & $\cdot$ & $\cdot$ & $\cdot$ & $\cdot$ & $\cdot$ & $\cdot$ & • & • & • & • & • & 11 \\
\hline & 22 & $\cdot$ & $\cdot$ & $\cdot$ & & $\cdot$ & $\cdot$ & $\cdot$ & $\cdot$ & $\cdot$ & $\cdot$ & $\cdot$ & 10 \\
\hline & 23 & $\cdot$ & $\cdot$ & & $\cdot$ & $\cdot$ & & $\cdot$ & $\cdot$ & $\cdot$ & $\cdot$ & & 8 \\
\hline & 24 & & $\cdot$ & & $\cdot$ & $\cdot$ & & $\cdot$ & $\cdot$ & & $\cdot$ & & 6 \\
\hline & 25 & $\cdot$ & 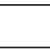 & & & $\cdot$ & & • & • & • & $\cdot$ & • & 7 \\
\hline & 26 & $\cdot$ & $\cdot$ & $\cdot$ & $\cdot$ & $\cdot$ & & $\cdot$ & $\cdot$ & $\cdot$ & $\cdot$ & $\cdot$ & 10 \\
\hline & 27 & $\cdot$ & $\cdot$ & $\cdot$ & $\cdot$ & $\cdot$ & $\cdot$ & • & • & • & - & • & 11 \\
\hline & 28 & & $\cdot$ & & $\cdot$ & $\cdot$ & & & $\cdot$ & $\cdot$ & $\cdot$ & & 6 \\
\hline & $\mathrm{T}$. & 21 & 20 & 8 & 19 & 24 & 12 & 18 & 21 & 16 & 24 & 14 & 197 \\
\hline
\end{tabular}

${ }^{(*)}$ The number corresponds to the title of each story as shown in Table 4.

Precedence of common interest (CIn); Appreciation of the interdependence relationships (Itd); Expanded sense of identity (EId); Sense of belonging to the community of life $(\mathrm{CmL})$; Synchronic co-responsibility (SCr); Diachronic co-responsibility (DCr; Solidarity and austerity (SaA); Empathy and affectivity (EaA); Respect for life and non-violence (LNv); Critical and active social attitude (CAA); Respectful and open to dialogue attitude (RDA)

The interpretation of the fragments according to their axiological loading leads us to conclude that there are many occasions in which the characters keep a sound consistency between their values and behaviours; show solidarity with future generations; put the common good in front of one's personal immediate interests. In these cases, the 
narrative often has the added factor of a powerful emotional charge due to the situation itself in which actors are immersed. That happens, for instance, when - keeping the theoretical and practical coherence - the deer majestically stood up straight and walked towards danger; since, having exempted the pregnant doe to do so, he had to replace her and could not send anyone in his place ("The Banyan Deer"). Or when the old man, whom the king recalls that, given his age, he cannot enjoy the fruits of his labour, smiles and says that his work is not in vain because his children and grandchildren will enjoy its fruits ("The Old Man and the Fig Tree"). Or when the buzzard, committed to the common good, even at the expense of his own health, “... flew until he reached the top of the sky, and there he placed the Sun where it would give light to everyone" ("How Grandmother Spider Stole the Sun"); a story in which prevails the idea that common interest - whether it is a social or ecological interest - has priority over personal concerns.

Likewise, we have very often appreciated the display of feelings of respect, affection, consideration and care, even compassion for other non-human beings or non-living elements of nature. Ultimately, the characters adopt an attitude of respect for life and for the exercise of non-violence before the conflicts, trying to prevent damage to any other living being or inert element of nature. Some examples are:

An Aboriginal hunter, silently stalking the wombat! Already his boomerang was raised above his head, its smooth edges ready to slice the air. The kangaroo froze. She couldn't even breathe. She wanted to run, but the wombat was like her joey - she had to protect him! ("How the Kangaroo Got Her Pouch")

As soon as he saw the swan fall, Siddartha ran over to it and carefully pulled out the arrow, he took some leaves and began to wipe the blood away. He nursed the bird in his arms, stroking its white feathers. " Buddha and the Swan")

... everyone has the responsibility to protect the peace (...) He instructed the men to cast down their weapons of war into the cavity to bury their greed, hatred and jealousy. (...) With his powers of persuasion he won them over. ("The Peacemaker and the Tree of Peace")

I have come so that two others need not die. Now shoot! You have your work and I have mine. ("The Banyan Deer")

And Man knew (...) that all creatures were his spirit cousins (...) when the spirits of all creatures become tired they join the Spirit of Life in the Land. So this is why the Land is sacred and man must be its Caretaker. ("The Secret of Dreaming”)

These extracted fragments are just illustrations of the many behaviours that, in more than $60 \%$ of the stories analysed, reflect values and attitudes. We consider that all of these, given their consistency with the values required by the Earth Charter, should be a formative objective in schools. Only in this way we can respond to the appeal made by the Earth Charter to exercise it (ECI, 2000).

... we, the peoples of Earth, declare our responsibility to one another, to the greater community of life, and to future generations. (Preamble) 
... to live with a sense of universal responsibility, identifying ourselves with the whole Earth community as well as our local communities. (Preamble)

Everyone shares responsibility for the present and future well-being of the human family and the larger living world. (Preamble)

Affirm that with increased freedom, knowledge, and power comes increased responsibility to promote the common good. (Principle I.2.b)

... with the right to own, manage, and use natural resources comes the duty to prevent environmental harm and to protect the rights of people. (Principle I.2.a)

Consequently, it can be said that mythical stories are valuable resources for the development of values and attitudes within the framework of education for sustainable development.

Our results contribute to strengthen the research line on experiences and practical applications of mythical-metaphorical narratives as an educational resource, providing a novel vision into a largely unexplored research direction. Thus, our research could be considered as an innovative contribution to the field of environmental education for sustainable development, specifically its epistemological principles and core values. It is, moreover, well-known that narrative materials are one of the most enriching resources to access knowledge, besides being one of the most appropriate sources to grasp the human experience (Mateos Blanco \& Nuñez Cubero, 2011). It has to be certainly considered as a valuable educational resource, very pertinent and complementary in the context of the already numerous international experiences which have the Earth Charter as a central reference of its training model (Arenas Ortiz, Hinojosa Pareja, \& López López, 2013).

\section{Conclusions}

The results of this research show a sound coherence between the texts of the mythical stories analysed and the epistemological principles, values and attitudes that we find in the Earth Charter. And, given that, this is a referential text in education for sustainable development, we can assert that these narratives should be considered as a potential resource for quality in educational processes in the framework of this model. We might treat this resource either as a starting point for motivation in educational activities or, with an instrumental character in pedagogical designs, to promote sustainability in the curriculum, especially in school education levels. Through this process, principles, values and procedures of the education for sustainable development model could permeate the teaching process of the educational centre and the different subjects taught in it. Or we might well treat this resource simply for values education, through mere storytelling, in formal, non-formal and informal environments.

Additionally, this research has allowed us to begin the construction of a repository of myths, legends and other metaphorical materials relevant for conveying the principles and values of sustainability that the Earth Charter calls us to practice. This work represents an approach to social and educational functions of myth and metaphorical stories, whose potential as an educational resource is worth exploiting for improving the quality of education. 
On the other hand, it has been observed that the greatest part of the identified mythical stories belongs to Native American cultures and traditions, with a total absence of European mythical and metaphorical materials. This limitation needs to be corrected and offers an invitation to undertake a search and analysis of mythical, metaphorical stories related to the European cultural traditions.

Furthermore, at present, when narrative approaches seem to gain a foothold in social sciences and humanities, this would open up interesting possibilities to complement and increase the educational resources available to teachers. Within the school context, this approach would require the highest possible contextualisation of activities, trying pathways, such as the "emotional closeness with nature", the imaginative combination of stories with sensory awareness experiences or the organisation of collaborative learning groups in virtual environments. The potentials for an educational use of mythical, metaphorical narratives are as wide as the creativity that teachers bring into play. This work provides a starting point for the context of education for sustainable development, with the support of the Earth Charter.

Finally, it is worth mentioning here that there is interest in expanding this research to include new myths that have been conceived in recent decades. Literary and film narratives which contain all the symbolic and archetypal ingredients of myths from the past seem to have emerged from the collective unconscious as a response to the critical needs of humanity today. Works like "The Lord of the Rings", "Star Wars", "Matrix" or "Avatar", among many others, could play a crucial role in the face of the challenges we are confronting in a historical situation never before experienced, such as globalisation and the serious social and environmental crises in which the world currently finds itself.

Campbell \& Moyers (1991), similar to Jung, said that myths "are the world's dreams. They are archetypal dreams and deal with great human problems" (p. 21). Perhaps these new myths are carrying, in their symbolic framework, responses that are emerging from the human collective unconscious to solve its current problems: the union of very different peoples and cultures to face the great crisis ("The Lord of the Rings"); the awakening of a new and different view of reality that allows us to "see" clearly our problems ("Matrix"); the close interrelation and interconnection among all living beings on the planet under the archetypal symbol of the axis mundi, the Tree of Life ("Avatar").

\section{Acknowledgement}

This survey was conducted within the EDUCAMDES Group of the UNESCO Chair of Environmental Education and Sustainable Development. It is a result of the project "New strategies for the excellence of the training processes in the context of the EHEA: The case of environmental education for sustainable development", which has been conducted in the framework of the IV Call for Investigation Networks for Teaching Innovation: Development of Pilot Projects for Teaching Adaptation to the European Space of the Vice-chancellorship of Quality and Teaching Innovation and the University Institute of Distance Education, UNED (Spain). 


\section{References}

Antunes, A. \& Gadotti, M. (2005). Eco-pedagogy as the appropriate pedagogy to the Earth Charter process. In P. B. Corcoran (Ed.), The Earth Charter in action: Toward a sustainable world (pp. 135-137). Amsterdam: KIT Publishers.

Arenas Ortiz, M., Hinojosa Pareja, F., \& López López, M. C. (2013). La Carta de la Tierra: experiencias internacionales de innovación en Educación Superior [The Earth Charter: International experiences of innovation in higher education]. Teoría de la Educación Revista Interuniversitaria [Theory of Education: Interuniversity Journal], 25(1), 79-107.

Arocha, J. (1994). Gregory Bateson, reunificador de mente y naturaleza [Gregory Bateson, a unifier of mind and nature]. Bogotá, Colombia: Universidad Central.

Aznar, P., \& Ull, M. A. (2013). La Responsabilidad por un mundo sostenible [Responsibility for a sustainable world]. Bilbao: Desclée de Brouwer.

Aznar, P., Martinez-Agut, M. P., Palacios, B., Piñero, A., \& Ull, A. (2011). Introducing sustainability into university curricula: An indicator and baseline survey of the views of university teachers at the University of Valencia. Environmental Education Research, 17(2), 145-166.

Barrón, Á., Navarrete, A., \& Ferrer-Balas, D. (2010). Sostenibilización curricular en las universidades españolas. Ha llegado la hora de actuar? [Curricular sustainability in a Spanish university. Is it time to act?]. Revista Eureka sobre Enseñanza y Divulgación de las Ciencias [Eureka Journal on Teaching and Sciences Dissemination], 7, 388-399.

Beringer, A. (2007). Ecological identities as foundation for sustainability competencies: Contributions from conservation psychology and sustainable campuses. Retrieved from http://ambiental.uaslp.mx/eventos/HESD07/Extensos/023_HESD07-FullTextBeringer_VF.pdf

Batelaan, P., \& Passantino, F. (2000). The big myth: An intercultural complex instruction unit on the Internet. Intercultural Education, 11(3), 35-39.

Boardman, J., \& Sauser, B. (2008). Systems thinking: Coping with 21st century problems. Boca Raton, FL: CRC Press.

Brody, E., Goldspinner, J., Green, K., \& Leventhal, R. (Eds.). (2002). Spinning tales, weaving hope: Stories, storytelling, and activities for peace, justice and the environment. Gabriola Island, BC. Canada: New Society Publishers.

Brown, J. E. (1982). The spiritual legacy of the American Indian. New York: Crossroad. Brown, J. E. (1989). The sacred pipe. Norman: University of Oklahoma Press.

Bruchac, J., \& Caduto, M. J. (1995). Native plant stories. Golden, CO: Fulcrum.

Caduto, M. J. (1984). Nature in native American myths: A program in environmental ethics. Nature Study, 38(1), 3-5.

Caduto, M. J., \& Bruchac, J. (1988). Keepers of the Earth: Native American stories and environmental activities for children. Golden, CO: Fulcrum.

Caduto, M. J., \& Bruchac, J. (1991). Keepers of the animals: Native American stories and wildlife activities for children. Golden, CO: Fulcrum.

Caduto, M. J., \& Bruchac, J. (1994a). Keepers of life: Discovering plants through Native American stories and Earth activities for children. Golden, CO: Fulcrum.

Caduto, M. J., \& Bruchac, J. (1994b). Keepers of the night: Native American stories and nocturnal activities for children. Golden, CO: Fulcrum.

Campbell, J., \& Moyers, B. (1991). The power of myth. New York: Anchor Books. 
Cary, M. B. (2007). The Earth Charter as a pedagogical tool for sustainability at Yerevan State University, Armenia. In M. Vilela \& K. Corrigan (Eds.), Good practices using the Earth Charter (pp. 121-126). San José de Costa Rica: UNESCO/ECI.

Cid, F. (2009). El "Kamishibai” como recurso didáctico en el aula de Educación Infantil y Primaria: una experiencia educativa. Propuestas para un entendimiento OrienteOccidente [The "Kamishibai" as a teaching resource in a primary education classroom: An educational experience. Proposals for an east-west understanding]. Bordón [Staff], 61(4), 141-152.

Cidoncha, V. (2011). Aprende matemáticas con los cuentos [Learn mathematics with stories]. La Revista Digital Educativa Wadi-red [Wadi-red Digital Learning Journal], 1(2), 138-144.

Choegyal Rinpoche, D. (2012). The Shambhala prophecy. In M. Harland \& W. Keepin (Eds.), The song of the Earth (pp. 99-100). East Meon: Permanent Publications.

De Cora, M. M. (2005). Kuay-Mare: Mitos aborígenes de Venezuela [Kuay-Mare: Indigenous myths from Venezuela]. Caracas: Monte Ávila.

Delgado, J. (2008). El pensamiento complejo: realidad o utopía en la educación postgraduada? [Complex thinking: Reality or utopia in postgraduate education?] Revista Iberoamericana de Educación [Latin American Education Journal], 47(4), 1-7.

Delgado, M. A., \& Del Villar, F. (1995). El análisis de contenido en la investigación de la enseñanza [Content analisys in teaching research]. Motricidad: Revista de Ciencias de la Actividad Física y del Deporte [Mobility: Journal of Sciences of Physical Activity and Sport], 1, 25-44.

Dmitrieva, V. (1997). The legend of Shambhala in eastern and western interpretations (Unpublished doctoral dissertation). McGill Universtity, Montreal, Canada.

Earth Charter Initiative (ECI). (2000). The Earth Charter. Retrieved from http://www.earthcharterinaction.org/invent/images/uploads/echarter_english.pdf

Egan, K. (1986). Teaching as story telling: An alternative approach to teaching and curriculum in the elementary school. Chicago, IL: The University of Chicago Press.

Egan, K. (2012). Primary understanding: Education in early childhood. Milton Park and New York: Routledge.

Ellis, B. (2012). Learning from the land: Teaching ecology through stories and activities. Santa Barbara, CA: Libraries Unlimited.

Fernández Herrería, A., \& Carmona, G. (2010). Trabajando la Carta de la Tierra: una experiencia de aprendizaje vivencial [Working with the Earth Charter: An experience of existential learning]. Revista de Ciencias de la Educación [Journal of Education Sciences], 221, 107-118.

First People. (2012a). The peacemaker and the tree of peace. Retrieved from http://www.firstpeople.us/FP-Html-Legends/ThePeacemakerAndTheTreeOfPeaceIroquois.html

First People. (2012b). Hiawatha the unifier. Retrieved from http://www.firstpeople.us/ FP-Html-Legends/Hiawatha-The-Unifier-Iroquois.html

First People. (2012c). How fox saved the people. Retrieved from http://www.first people.us/FP-Html-Legends/How_Fox_Saved_The_People-Eskimo.html

First People. (2012d). The legend of the first woman. Retrieved from http://www.first people.us/FP-Html-Legends/TheLegendOfTheFirstWoman-Cherokee.html

Fisher, R. (1996). Stories for thinking. Winsford, UK: Nash Pollock. 
Flood, B., Strong, B. E., \& Flood, W. (1999). Pacific Island legends: Tales from Micronesia, Melanesia, Polynesia and Australia. Honolulu, Hawaii: Bess Press.

Fuller-Anderson, L. (2011). Warriors of the rainbow. Salina: Indian Territories Collections. Gadotti, M. (2000): Pedagogía de la Tierra [Pedagogy of the Earth]. Sao Paulo: Petrópolis.

Geli, A. M. (2005). Una propuesta metodológica de orientación hacia la sostenibilidad en los estudios superiores: caracterización y evaluación [A methodological proposal towards sustainability in higher education: Characterisation and evaluation]. Enseñanza de las Ciencias: Revista de Investigación y Experiencias Didácticas [Teaching Science: Journal of Research and Teaching Experiences], Special Issue, $1-7$.

González León, C. (2010). El mito: contenido y método de la pedagogía del arte [The myth: Content and methodology of art pedagogy]. (Pensamiento), (palabra) y obra [(Thinking), (Word) and Work], 4(4), 4-11.

Hedlund-de Witt, A. (2013). Worldviews and their significance for the global sustainable development debate. Environmental Ethics, 35(2), 133-162.

Hedlund-de Witt, A., de Boer, J., \& Boersema, J. (2014). Exploring inner and outer worlds: A quantitative study of worldviews, environmental studies, and sustainable lifestyles. Journal of Environmental Psychology, 37, 40-54.

Inelmen, E. (2010). Implementing "system thinking" in the design of a "learning environment". Procedia - Social and Behavioral Sciences, 2(2), 501-506.

Indian Stories. (n. d.). Firstman and firstwoman. Retrieved from http://indianstories. awardspace.com/webdoc23.htm

Jansen, B. A., \& Culpepper, S. N. (1996). Using the big six research process. The coconut crab from Guam and other stories: Writing myths, fables, and tall tales. MultiMedia Schools, 3(5), 32-38.

Leeming, D. A. (2010). Creation myths of the world: An encyclopedia. Santa Barbara, CA: ABC-CLIO.

Livo, N. J. (2000). Celebrating the earth: Stories, experiences, and activities. Englewood, CO: Teacher Ideas Press.

Livo, N. J. (2003). Bringing out their best: Values education and character development through traditional tales. Wesport, CT: Libraries Unlimited.

López Valero, A., \& Encabo, E. (2001). De mitos, leyendas y cuentos: necesidad didáctica del género narrativo [On myths, legends and stories: The didactic need of the narrative genre]. Contextos Educativos: Revista de Educación [Educational Contexts: Journal of Education], 4, 241-250.

López Valero, A., Encabo, E., Moreno, C., \& Jerez, I. (2003). Cómo enseñar a través de los mitos: la didáctica de la Lengua y la Literatura en una fábula alegórica [How to teach through myths: The didactics of language and literature in an allegorical fable]. Didáctica (Lengua y Literatura) [Didactics (Language and Literature)], 15, 121-138.

Macdonald, M. R. (1999). Earth care: World folktales to talk about. Atlanta: August House Inc.

Macy, J. (2002). The Shambhala warrior. Retrieved from http://www.ijourney.org/ index.php?tid=236

Marín, M. (1999). El valor del cuento en la construcción de conceptos matemáticos [The value of the story in the construction of mathematical concepts]. Números [Numbers], 39, 27-38. 
Marín, M. (2003). Cuentos para aprender matemáticas [Stories to learn mathematics]. ACTAS III Jornadas Provinciales de Matemáticas [Proceedings of the 3rd Regional Conference of Mathematics] (pp. 89-102). Madrid: Consejería de Educación de la Comunidad de Madrid.

Marín, M. (2007). El valor matemático de un cuento [The mathematical value of a story]. Sigma: Revista de Matemáticas [Sigma: Mathematics Journal], 31, 11-26.

Martin, R. (1990). The hungry tigress: Buddhist legends and Jataka tales. Berkeley, CA: Parallax Press.

Mateos Blanco, T., \& Núñez Cubero, L. (2011). Narrativa y educación: indagar la experiencia escolar a través de los relatos [Narrative and education: Explore the school experience through short stories]. Teoría de la Educación Revista Interuniversitaria [Theory of Education: Interuniversity Journal], 23(2), 111-128.

McFadden, S. (1989). Legend of the rainbow warriors. Lincoln, NE: The Harlem Writers Guild Press.

Morin, E. (1992). From the concept of system to the paradigm of complexity. Journal of Social and Evolutionary Systems, 15(4), 371-385.

Morin, E. (1996). A new way of thinking. The UNESCO Courier, 49(2), 10-14.

Morin, E. (2001). Seven complex lessons in education for the future. Retrieved from http://unesdoc.unesco.org/images/0011/001177/117740eo.pdf

Murga-Menoyo, M. A. (2009). La Carta de la Tierra: un referente de la Década por la Educación para el Desarrollo Sostenible [The Earth Charter: A reference to the United Nations Decade of Education for Sustainable Development]. Revista de Educación [Journal of Education], Special issue 2009, 239-262.

Murga-Menoyo, M. A. (2013). Desarrollo sostenible. Problemáticas, agentes y estrategias [Sustainable development. Challenges, agents and strategies]. Madrid: MacGraw Hill.

Novo, M. (2006). El desarrollo sostenible: su dimensión ambiental y educativa [Sustainable development: The environmental and educational perspective]. Madrid: Pearson.

Ogumefu, M. J. (2007). Yoruba legends. Retrieved from http://www.forgottenbooks.org/ ebooks/Yoruba_Legends_-_9781605060170.pdf

Ovsienko, L. V. (2007). Reorienting Tatarstan's educational system towards education for sustainability. In M. Vilela \& K. Corrigan (Eds.), Good practices using the Earth Charter (pp. 54-59). San José de Costa Rica: Unesco/ECI.

Páez, R. M. (2011). Narración mítica: necesario tejido espiritual en la formación de los niños [Mythical narrative: Spiritual tissue needed for the education of children]. Revista Iberoamericana de Educación [Latin American Journal of Education], 54(5), $1-12$.

Palacio, C. A., \& Ochoa, F. L. (2011). Complejidad: una introducción [Complexity: An introduction]. Ciência \& Saúde Coletiva [Joint Science and Health], 16, 831-836.

Jacobson, M., \& Wilensky, U. (2006). Complex systems in education: Scientific and educational importance and implications for the learning sciences. The Journal of the Learning Sciences, 15(1), 11-34.

Poultier, J. (1988). The secret of dreaming: The story of why the land is sacred and why man must be its caretaker. Templestowe: Red Hen.

Saá Rojo, M. D. (2002). Las matemáticas de los cuentos y las canciones [The mathematics of stories and songs]. Madrid: Editorial EOS. 
Schiller, P., \& Peterson, L. (1997). Count on math: Activities for small hands and lively minds. Lewisville, NC: Gryphon House.

Swaim, S. (1997). Dancing a story: Myth and movement for children. Early Childhood Education Journal, 25(2), 127-131.

Taylor, B. (2000). Deep ecology and its social philosophy: A critique. In E. Katz, A. Light \& D. Rothenberg (Eds.), Beneath the surface: Critical essays in the philosophy of deep ecology (pp. 269-299). Cambridge, MA: MIT Press.

UN (United Nations). (2011). Learning for the future: Competences in education for sustainable development. Geneva: United Nations Economic Commission for Europe.

UNESCO (United Nations Educational, Scientific and Cultural Organisation). (1997). Educating for a sustainable future: A transdisciplinary vision for concerted action. Retrieved from http://unesdoc.unesco.org/images/0011/001106/110686eo.pdf

UNESCO (United Nations Educational Scientific and Cultural Organisation). (2003). Records of the general conference. Retrieved from, http:/unesdoc.unesco.org/images/ 0013/001331/133171e.pdf

UNESCO (United Nations Educational Scientific and Cultural Organisation). (2004). United Nations Decade of Education for Sustainable Development (2005-2014). Paris: UNESCO.

UNESCO (United Nations Educational Scientific and Cultural Organisation). (2005). Draft international implementation scheme for the United Nations Decade of Education for Sustainable Development. Paris: UNESCO.

UNESCO (United Nations Educational Scientific and Cultural Organisation). (2006). Framework for the UNDESD international implementation scheme. Paris: UNESCO.

UNESCO (United Nations Educational Scientific and Cultural Organisation). (2010). Education for sustainable development lens: A policy and practice review tool. Paris: Section for Education for Sustainable Development.

UNESCO (United Nations Educational Scientific and Cultural Organisation). (2012). Learning and training tools. Retrieved from, http://unesdoc.unesco.org/images/0021/ 002163/216383e.pdf

Vázquez, V. (2010). La perspectiva de la ética del cuidado: una forma diferente de hacer educación [The perspective of the ethics of care: A different way to education]. Educación XX1 [Education XX1], 13(1), 177-197.

Zabel, M. K. (1991). Storytelling, myths and folk tales: Strategies for multicultural inclusión. Preventing School Failure, 36(1), 32-34.

Correspondence concerning this paper should be addressed to María Ángeles MurgaMenoyo, PhD, Professor and Head of the Department of Theory of Education and Social Pedagogy at the National Distance Education University, Juan del Rosal 14, 28040, Madrid, Spain. Email: mmurga@edu.uned.es; grian@avalonproject.org 